\title{
Clinical Analysis of Interventional Therapy for Eight Cases of Extracranial ICA Aneurysm
}

\author{
Jian-Feng $X u^{1}$, Zao-Bin $\mathrm{Liu}^{2}$, \\ Tong Wang ${ }^{3}$, Yang Liu ${ }^{4}$
}

\begin{abstract}
Objective: To explore the interventional therapy and clinical efficacy of extracranial ICA aneurysm.

Methods: The clinical data of eight patients with extracranial ICA aneurysm treated by interventional stent implantation from December 2014 to February 2018 in the Neurosurgery Department of the Third Hospital of Mianyang were analyzed. And this research was a retrospective analysis. All patients underwent digital subtraction angiography (DSA) and were diagnosed with extracranial carotid artery aneurysm. These patients, therefore, were treated with interventional stent implantation.

Results: Interventional treatment was successfully conducted on all eight patients. In eight patients, the aneurysm cavity was not developed immediately after angiography, and in one case, the aneurysm cavity was developed with coil-assisted embolization. All the internal carotid arteries were well developed, with no complications such as intraoperative rupture, bleeding and thrombosis occur. Follow-up for three months to two years showed that the patients recovered well, the GOS score was 4 points for patients with cerebral infarction, and the rest reached five points. Follow-up CTA showed no signs of aneurysm recurrence or ICA restenosis.

Conclusion: Interventional stent placement is a preferable and relatively safe method for the treatment of extracranial carotid artery aneurysm with less trauma and short operation time.
\end{abstract}

KEYWORDS: Aneurysm, Stent, Extracranial ICA, Interventional therapy.

doi: https://doi.org/10.12669/pjms.37.4.3957

How to cite this:

Xu JF, Liu ZB, Wang T, Liu Y. Clinical Analysis of Interventional Therapy for Eight Cases of Extracranial ICA Aneurysm. Pak J Med Sci. 2021;37(4):1086-1092. doi: https://doi.org/10.12669/pjms.37.4.3957

This is an Open Access article distributed under the terms of the Creative Commons Attribution License (http://creativecommons.org/licenses/by/3.0), which permits unrestricted use, distribution, and reproduction in any medium, provided the original work is properly cited.

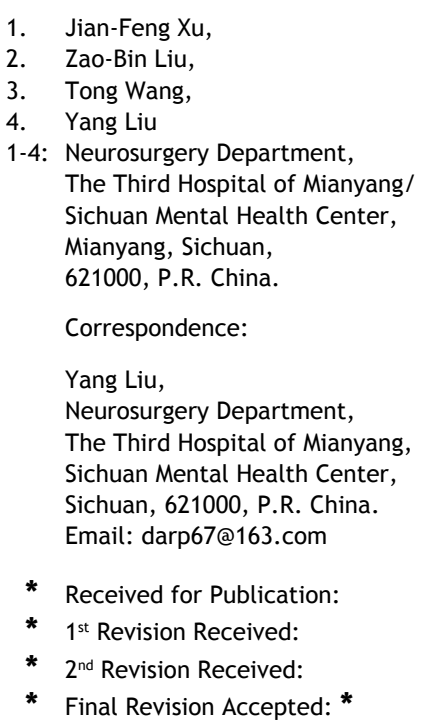

November 28, 2020

December 22, 2020

February 25, 2021

March 5, 2021

\section{INTRODUCTION}

Aneurysms of the extracranial internal carotid aneurysm (EICA) account for an estimated $0.1 \%$ to $2 \%$ of all carotid procedures and less than $1 \%$ of all arterial aneurysms. ${ }^{1}$ The most common underlying causes related to these true aneurysms include atherosclerosis, trauma, fibromuscular dysplasia, infection, connective tissue disorders, and large vessel vasculitis. ${ }^{2}$ EICA generally has no obvious clinical symptoms. Some patients usually show pain, throbbing masses or cranial nerve palsy. ${ }^{3}$ In some medical centers, EICA accounts for only $0.1 \%-2 \%$ of carotid artery related operations. ${ }^{4}$ EICA contributes to high-level factors such as local compression and the formation of mural thrombus shedding, leading to a high incidence of stroke events. Therefore, patients should actively undergo 
surgical intervention once they are diagnosed with EICA. ${ }^{5}$ For such disease, surgical treatment and interventional therapy have been reported in the past. Endovascular interventional therapy, however, has the characteristics of minimally invasive, less neurovascular injury and fewer postoperative complications, which is often used as the preferred treatment strategy. In this paper, the clinical data of patients with EICA treated by interventional stent implantation in our center were analyzed retrospectively, and the interventional treatment and clinical efficacy were explored.

\section{METHODS}

Ethical approval: The study was approved by the Institutional Ethics Committee of The Third Hospital of Mianyang/Sichuan Mental Health Center at August 29, 2020, and written informed consent was obtained from all participants.

Methods: This research was a retrospective analysis. And PASS software was used to calculate the sample size. Of eight patients with EICA treated by interventional stent implantation from December 2014 to February 2018 in the Third Hospital of Mianyang were analyzed retrospectively. Six male and two female patients were enrolled into this group of cases. The age ranged from 41 - 66 years, with an average age of 50.5 years. Among the eight patients, five cases showed dizziness, one case was found to have intracranial aneurysm during followup, one case had sudden limb paralysis during CT examination, and one case had brain stem hemorrhage in rehabilitation period.
Imaging examination: All patients were first diagnosed with EICA by CTA, and one patient with cerebral infarction was complicated with contralateral internal carotid stenosis. All patients underwent digital subtraction angiography (DSA) and were diagnosed with EICA.

Therapeutic method: All patients received interventional therapy. $100 \mathrm{mg}$ of aspirin and 75 $\mathrm{mg}$ of clopidogrel were taken orally before the operation for 3-5 days. During the treatment, three cases were given local anesthesia, four cases were treated with tracheal intubation general anesthesia, the right femoral artery was punctured and the sheath was inserted, the $8 \mathrm{~F}$ guide catheter was inserted, the cerebral angiography evaluation was performed first, and the 3D angiography evaluation was performed. Relevant data were measured based on the angiography results, including the diameter from the proximal end to the distal end of the inter carotid artery (ICA) around the aneurysm's neck, the width of the aneurysm's neck and the distance from the initial part of the ICA and the skull base. During the operation, heparinization was performed. In the road map mode, the guide wire of five patients passed through the distal end of the ICA at the aneurysm site, and then the stent was delivered and released around the aneurysm neck. Angiography showed that the aneurysm was not developed and the parent artery was unobstructed. In three patients, microcatheter was inserted into the aneurysms under the guidance of micro-guide wire. The coils were embolized, and then the aneurysmal neck was covered with stents. Low
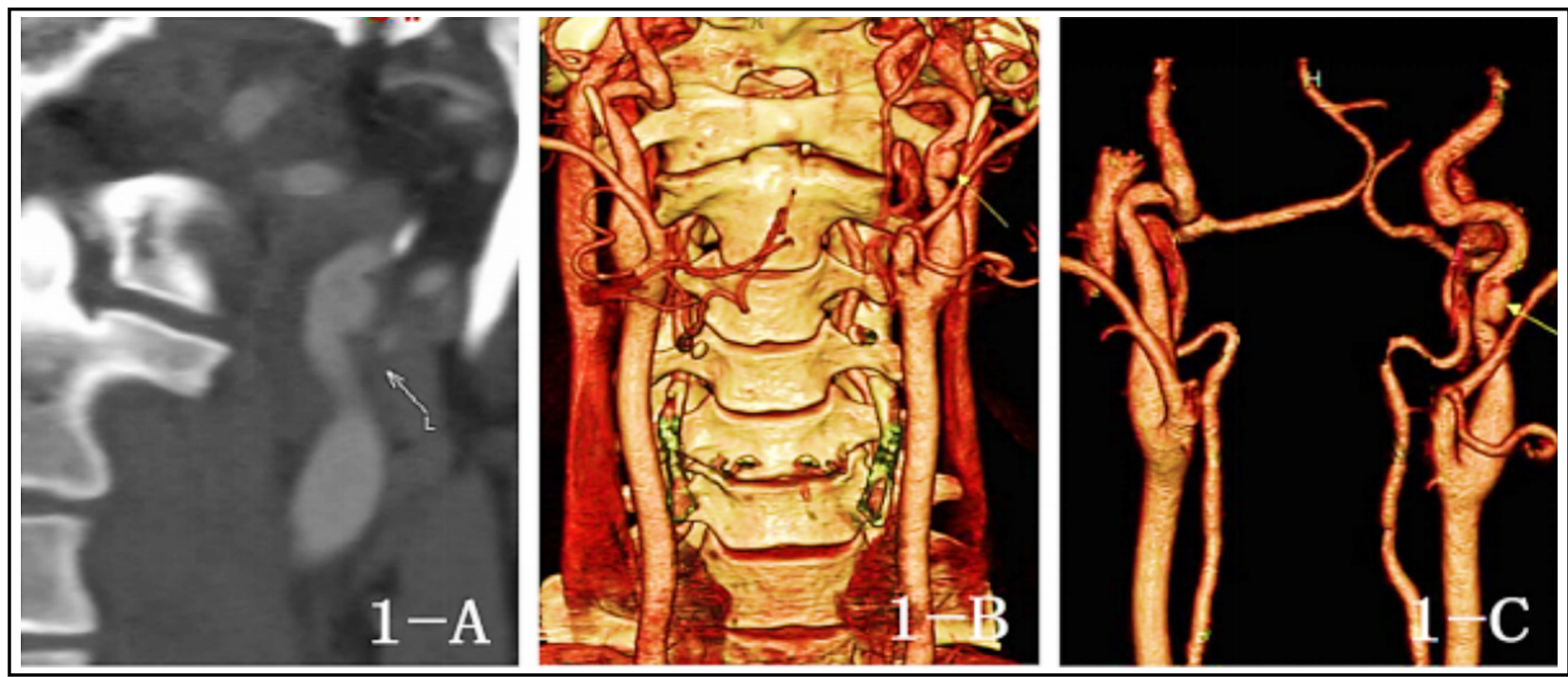

Fig.1. Preoperative CTA images

Fig.1-A: (MIP), Fig.1- B, 1-C: (Reconstruction Image) revealed left extracranial carotid artery aneurysm, Size: $5 * 8 m m$. 


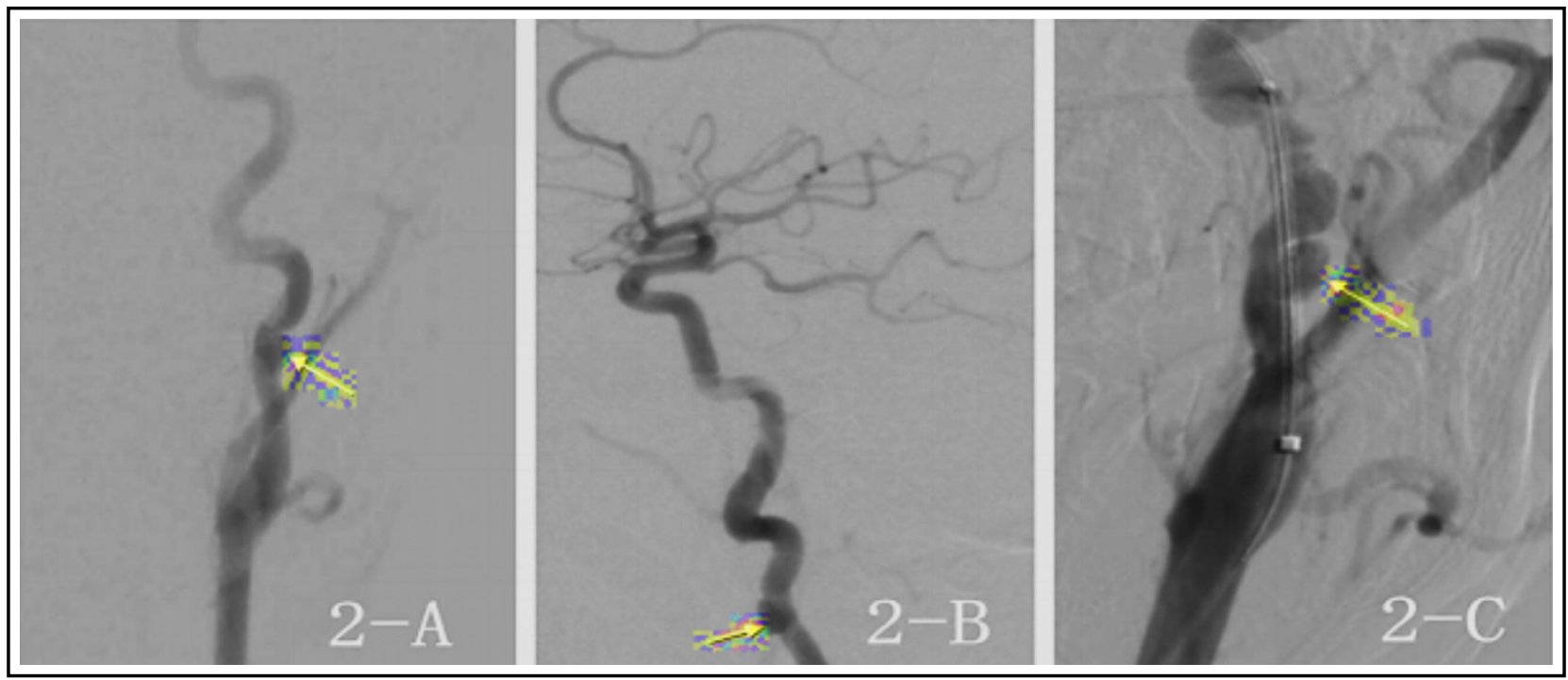

Fig.2: Intraoperative DSA Images

Fig.2-A: Left internal carotid angiography (Anteroposterior position), Fig. 2-B: Left internal carotid angiography (Lateral position), Fig. 2-C: Stent Implantation with Parent Artery of Left extracranial carotid artery aneurysm.

molecular weight heparin (LMWH) was injected subcutaneously for three days after the operation. Aspirin was routinely taken orally for six months and clopidogrel for three months. One patient was recommended to take aspirin for a long time due to multiple high-risk factors for cardiovascular and cerebrovascular diseases.

\section{RESULTS}

Basic information of cases (As shown in Table-I): Case 1: Basic information: male, 50 years old.
Chief complaint: pain in the right occiput posterior position and the top of the head for $6+$ days. Imaging examination: CTA: left ICA dissecting aneurysm with artery stenosis. DSA: Left extracranial carotid artery aneurysm, about $5^{*} 8 \mathrm{~mm}$ in size, with irregular shape and local carotid artery stenosis (see Fig.1, 2, 3 and Table-I).

Case 2: Basic information: female, 46 years old. Chief complaint: Three months after the intracranial aneurysm operation, the right extracranial carotid artery aneurysm was found for $10+$ days. Imaging
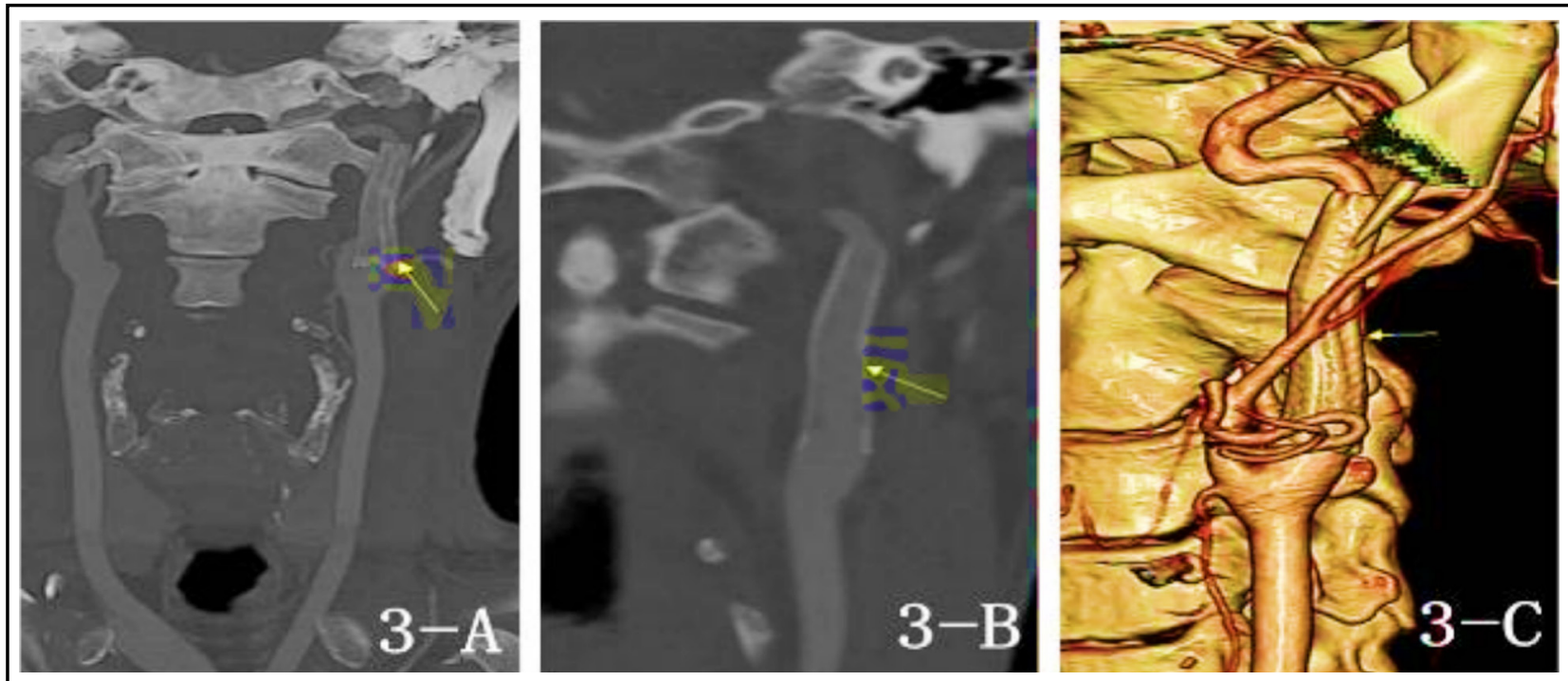

Fig.3: CTA image for 1-year postoperative follow-up

Fig.3-A, Fig.3-B: (MIP) and Fig.3-C: (Reconstruction Image) showed the stent had no displacement and the blood flow was unobstructed). 
Table-I: Statistical graph of basic treatment information of patients.

\begin{tabular}{|c|c|c|c|c|c|c|c|c|c|c|c|c|}
\hline $\begin{array}{l}P a- \\
\text { tient } \\
\text { No. }\end{array}$ & Gender & Age & $\begin{array}{c}\text { Prox- } \\
\text { imal } \\
\text { diam- } \\
\text { eter } \\
\text { of } \\
\text { ICA } \\
\text { of } \\
\text { aneu- } \\
\text { rysm }\end{array}$ & $\begin{array}{l}\text { Distal } \\
\text { diam- } \\
\text { eter of } \\
\text { ICA } \\
\text { of } \\
\text { aneu- } \\
\text { rysm }\end{array}$ & $\begin{array}{l}\text { Width } \\
\text { of } \\
\text { aneu- } \\
\text { rysm } \\
\text { neck }\end{array}$ & Treatment & $\begin{array}{l}\text { Brand } \\
\text { of } \\
\text { stent }\end{array}$ & $\begin{array}{l}\text { Type of } \\
\text { stent }\end{array}$ & Specifications & $\begin{array}{l}\text { Com- } \\
\text { plica- } \\
\text { tion }\end{array}$ & $\begin{array}{l}\text { Fol- } \\
\text { low-up } \\
\text { time }\end{array}$ & $\begin{array}{l}\text { Follow- } \\
\text { up } \\
\text { results } \\
\text { and } \\
\text { Rank } \\
\text { classifi- } \\
\text { cation }\end{array}$ \\
\hline 1 & Male & 50 & 4.8 & 3.9 & 5 & $\begin{array}{l}\text { Stent im- } \\
\text { plantation } \\
\text { alone }\end{array}$ & $\begin{array}{l}\text { Ab- } \\
\text { bott }\end{array}$ & $\begin{array}{l}\text { Accu- } \\
\text { link }\end{array}$ & $\begin{array}{l}6 \mathrm{~mm}^{*} 8 \mathrm{~mm} \\
{ }^{*} 40 \mathrm{~mm} \text { coni- } \\
\text { cal stent }\end{array}$ & None & $\begin{array}{c}4 \\
\text { years }\end{array}$ & $\begin{array}{c}\text { Good, } \\
5\end{array}$ \\
\hline 2 & Female & 45 & 4.9 & 3.2 & 4.7 & $\begin{array}{l}\text { Stent im- } \\
\text { plantation } \\
\text { alone }\end{array}$ & Bard & $\begin{array}{l}\text { FVL } \\
06040\end{array}$ & $6 \mathrm{~mm} * 40 \mathrm{~mm}$ & None & $\begin{array}{c}2 \\
\text { years }\end{array}$ & $\begin{array}{c}\text { Good, } \\
5\end{array}$ \\
\hline 3 & Male & 66 & 3.9 & 3.5 & 4.9 & $\begin{array}{l}\text { Stent im- } \\
\text { plantation } \\
\text { alone }\end{array}$ & Bard & $\begin{array}{l}\text { FVL } \\
06040\end{array}$ & $6 \mathrm{~mm} * 40 \mathrm{~mm}$ & None & $\begin{array}{c}3 \\
\text { years }\end{array}$ & $\begin{array}{c}\text { Good, } \\
5\end{array}$ \\
\hline 4 & Male & 46 & 5.1 & 4.05 & 3.4 & $\begin{array}{l}\text { Stent } \\
\text { placement } \\
+ \text { coil } \\
\text { emboliza- } \\
\text { tion }\end{array}$ & EV3 & $\begin{array}{l}\text { Protege } \\
\text { carotid } \\
\text { artery } \\
\text { stent }\end{array}$ & $\begin{array}{l}\text { 1) } 6 \mathrm{~mm} \\
* 8 \mathrm{~mm} \\
{ }^{*} 40 \mathrm{~mm} \text { coni- } \\
\text { cal stent } \\
\text { 2) Coils } \\
\text { : Aux- } \\
\text { ium } 6 \mathrm{~mm} \\
\text { *30mm¹ }\end{array}$ & None & $\begin{array}{c}2 \\
\text { years }\end{array}$ & $\begin{array}{c}\text { Good, } \\
4\end{array}$ \\
\hline 5 & Male & 41 & 5.09 & 3.78 & 8.67 & $\begin{array}{l}\text { Stent } \\
\text { placement } \\
+ \text { coil } \\
\text { emboliza- } \\
\text { tion }\end{array}$ & EV3 & $\begin{array}{l}\text { Solitare } \\
\mathrm{AB}\end{array}$ & $\begin{array}{l}\text { 1) Stent: } \\
6 \mathrm{~mm} * 30 \mathrm{~mm} \\
\text { 2) Coils: } \\
\text { Auxium } \\
7 \mathrm{~mm} * 30 \mathrm{~mm} \\
{ }^{*} 1, \\
6 \mathrm{~mm}{ }^{*} 20 \mathrm{~mm} \\
{ }^{*} 1\end{array}$ & None & $\begin{array}{c}1 \\
\text { years }\end{array}$ & $\begin{array}{c}\text { Good, } \\
5\end{array}$ \\
\hline 6 & Male & 54 & 4.2 & 5.3 & 14.1 & $\begin{array}{l}\text { Stent im- } \\
\text { plantation } \\
\text { alone }\end{array}$ & EV3 & $\begin{array}{l}\text { Protege } \\
\text { carotid } \\
\text { artery } \\
\text { stent }\end{array}$ & $7 \mathrm{~mm}^{*} 40 \mathrm{~mm}$ & None & $\begin{array}{c}2 \\
\text { years }\end{array}$ & $\begin{array}{c}\text { Good, } \\
5\end{array}$ \\
\hline 7 & Female & 60 & 5.1 & 4.5 & 5 & $\begin{array}{l}\text { Stent } \\
\text { placement } \\
+ \text { coil } \\
\text { emboliza- } \\
\text { tion }\end{array}$ & EV3 & $\begin{array}{l}\text { Solitare } \\
\mathrm{AB}\end{array}$ & $6 \mathrm{~mm}^{*} 30 \mathrm{~mm}$ & None & $\begin{array}{c}1 \\
\text { years }\end{array}$ & $\begin{array}{c}\text { Good, } \\
5\end{array}$ \\
\hline 8 & Male & 41 & 5 & 4.85 & 5.6 & $\begin{array}{l}\text { Stent } \\
\text { placement } \\
+ \text { coil } \\
\text { emboliza- } \\
\text { tion }\end{array}$ & $\begin{array}{l}\text { 1) } \\
\text { EV3 } \\
\text { 2) BA } \\
\text { LT }\end{array}$ & $\begin{array}{l}\text { Soli- } \\
\text { taire } \\
\text { AB }\end{array}$ & $\begin{array}{l}\text { 1) Stent: } \\
6 \mathrm{~mm} * 30 \mathrm{~mm} \text {. } \\
\text { 2) Coils: } \\
\text { Auxium } \\
5 \mathrm{~mm}{ }^{*} 15 \mathrm{~mm} \\
{ }^{*} 1,3 \mathrm{~mm} \\
{ }^{*} 8 \mathrm{~mm}{ }^{*} 2\end{array}$ & None & $\begin{array}{c}2 \\
\text { years }\end{array}$ & $\begin{array}{c}\text { Good, } \\
5\end{array}$ \\
\hline
\end{tabular}


examination: CTA: postoperative performance of right extracranial carotid artery aneurysm, and intracranial aneurysm clipping. DSA: right extracranial carotid artery aneurysm, about $8^{*} 4 \mathrm{~mm}$ in size and irregular in shape.

Case 3: Male, 66 years old. Chief complaint: paroxysmal amaurosis in left eye for 1 week. Imaging examination: head and neck CTA: dissecting aneurysm of the left ICA Cranial DSA: dissecting aneurysm of the left extracranial ICA.

Case 4: Male, 46 years old. Chief complaint: dizziness for 9 hours, aggravated with weakness of right limb for $6+$ hours. Imaging examination: head and neck CTA: 1 . Tumor-like nodules are prominent in the distal segment of the right ICA, suggesting aneurysms. 2. Local lumen stenosis in the cervical segment of the left ICA; 3 . A large area of slightly low-density shadow was seen in the left basal ganglia and left parietal lobe. DSA: 1. Aneurysm at the distal end of the extracranial segment of the right ICA, about 6 * $7 \mathrm{~mm}$ in size; 2 . The stenosis in the middle section of the left ICA has changed.

Case 5: Male, 41 years old. Chief complaint: sudden weakness of the right limb with slurred speech for $7+$ months. Imaging examination: CTA: the lumen of the left ICA at the end of the petrous segment was widened and swelled to the medial navicular shape, showing double lumen, suggesting localized dissection with aneurysm formation. DSA: right extracranial carotid artery aneurysm, about $19^{*} 8 \mathrm{~mm}$ in size and irregular in shape.

Case 6: Basic information: male, 54 years old. Chief complaint: hypomnesis with fatigue of right upper limb for three months. Imaging examination: CTA: double lumen shadow was seen in the proximal segment of the left ICA, and low-density intimal film was seen in it, suggesting a localized dissecting aneurysm with a range of about $1.67 \mathrm{~cm}$. DSA: The dissection of the initial segment of the left ICA has changed, and irregular in shape.

Case 7: Female, 61 years old. Chief complaint: recurrent dizziness with visual rotation for 20 years, followed by limb shaking for 1 day. Imaging examination: DSA: 1. Left main aneurysm of ICA, about $13^{*} 10 \mathrm{~mm}$ in size.

Case 8: Male, 42 years old. Chief complaint: headache for 4+ days. Imaging examination: DSA suggests: 1 . Localized enlargement of the petrous bone segment of the right ICA; 2 . On the right vertebral artery angiography, the irregular enlargement of the distal segment of the vertebral artery was observed.

Outcomes: Eight patients were successfully treated. One patient complicated with contralateral ICA stenosis was treated with ICA stent implantation. After the operation, LMWH was injected subcutaneously for three days, aspirin was taken for six months and clopidogrel for three months. One patient complicated with multiple high-risk factors of cardiovascular and cerebrovascular diseases suggested taking aspirin for life. In seven patients, the aneurysm cavity was not developed immediately after angiography, and in one case, the aneurysm cavity was developed with coil-assisted embolization. All the internal carotid arteries were well developed, with no complications such as intraoperative rupture, bleeding and thrombosis occur. Follow-up for three months to two years showed that the patients recovered well, the GOS score was four points for patients with cerebral infarction, and the rest reached five points. Followup CTA showed no signs of aneurysm recurrence or ICA restenosis.

Typical case images presentation: Treatment of extracranial aneurysm of left ICA with stent implantation (Case 1), aneurysm marked by arrow.

\section{DISCUSSION}

Extracranial carotid artery includes the common carotid artery, the external carotid artery and the internal carotid artery (ICA) till the skull base. ${ }^{6}$ The EICA is defined as a dilation of $150 \%$ or more of the diameter of the expected normal carotid artery. ${ }^{7}$ EICA is rare and accounts for less than $1 \%$ of all peripheral artery aneurysms, and the pathogenesis is not yet clear. ${ }^{8}$ It may be related to dissections, atherosclerosis, infection, fibromuscular dysplasia, connective tissue disease and traumatic or spontaneous dissection. ${ }^{9,10}$ EICA is mainly located in the bifurcation of carotid artery or the distal end of ICA, ${ }^{11}$ accounting for $0.4 \%-4 \%$ of peripheral aneurysms and $1.5 \%$ of all carotid artery revascularization. The incidence of EICA in male is higher than that in female, with the ratio of about $3: 1$, and the average age of 61.9 years.

The development of EICA is gradually accompanied by neurological dysfunction, such as transient ischemic attack, aneurysm rupture and bleeding, thrombosis, cerebral infarction, peripheral nerve compression and so on. Studies by Jin ChunXiang et al. show that ${ }^{12}$ even if EICA has no relevant clinical manifestations, imaging examination suggests that early surgical treatment should be performed if cerebral blood supply is affected. Therefore, once the diagnosis is made, active surgical intervention is necessary. EICA is divided into conservative treatment and 
surgical intervention. Conservative treatment mainly includes anticoagulation and antiplatelet aggregation. It has been reported that, however, anticoagulation is ineffective, because the incidence of stroke is still $50 \%$ even under anticoagulation. Therefore, surgical treatment should still be the preferred treatment even for asymptomatic patients.

Surgical treatment mainly includes: surgical treatment, endovascular interventional therapy, surgical treatment combined with endovascular therapy, etc. Surgical treatment of EICA has been conducted for many years. Welleweerd JC et al. believe that ${ }^{13}$ surgery treatment is the accepted treatment method for symptomatic EICA, and complete aneurysm resection combined with vascular reconstruction was once considered as the gold standard method. However, surgical treatment has the disadvantages such as large trauma, easy to produce neurological deficits after surgery, etc. ${ }^{14}$ Surgical treatment combined with endovascular therapy is mainly aimed at EICA with large and near skull base and severe distortion of ICA.

Endovascular interventional therapy has the characteristics of minimally invasive, less neurovascular injury and fewer postoperative complications. ${ }^{15}$ Therefore, endovascular interventional therapy is more widely used in the treatment of EICA. Wellewerd Janna C et al. ${ }^{16}$ performed endovascular therapy on seven patients with symptomatic EICA. After the operation, the patients had no local or central nervous symptoms, and the thrombosis in the aneurysm was completely occluded, which proved that endovascular therapy of EICA aneurysms was technically feasible and safe. In our study, the internal carotid artery was well developed in all patients without intraoperative rupture, bleeding, thrombosis and other complications, which further verified the safety of endovascular interventional therapy. Han Daniel K et al. ${ }^{17}$ reported that a patient with multiple cranial EICA was successfully treated with stent-assisted coil embolization. Haruma J et al. ${ }^{18}$ performed endovascular treatment for a patient with EICA who had undergone endovascular resection and had a recurrence. After the operation, the parent artery was unobstructed and the aneurysm was not developed. The follow-up examination three months after the operation showed that EICA was completely occluded. Therefore, endovascular treatmentcanalso beapplied to patients undergoing re-operations to reduce the risk of surgery caused by local anatomical abnormalities. In recent years, endovascular interventional therapy has been more widely used in the treatment of EICA.

In the interventional therapy of EICA, stents, coils and balloons are commonly used. Stents include balloon expandable stents, self-expanding stents, and covered stents. In the treatment of this part of aneurysm, two cases were treated with covered stents, six cases with self-expanding stents, including three cases with carotid artery stents. Four patients were treated with stent isolation alone, and four patients were treated with coil-assisted stents for EICA. In recent years, the flow-diverting stent has been gradually applied to the treatment of EICA and achieved good results. ${ }^{19}$ According to Robijn SMM et al., ${ }^{20}$ a 21-year-old male patient with EICA was treated with flow-diverting stent. Six months after the operation, DAS showed that the aneurysm was occluded well without complications. In the treatment of EICA, coil embolization alone is rarely used, but usually combined with stent for endovascular treatment. Our research has further enriched the clinical data and research references for the application of intravascular interventional techniques in extracranial carotid aneurysms. It is center recommended by our center that for patients with extracranial ICA whose imaging changes are mainly in the form of dissection, carotid artery stents, covered stents or flow-diverting stents are the first choice to isolate the dissection and repair the blood vessels. Those with tumor cysts can be treated with stents (such as Solitaire stents) plus coil embolization. The sample size needs to be further expanded, and prospective control studies need to be conducted in the future owing to the small sample size and lack of long-term follow-up in this study.

Limitations of the study: There is no unified standard for diagnosis and treatment of EICAA, which needs to be further improved.

\section{CONCLUSION}

Interventional stent implantation or coil-assisted embolization is a preferable and relatively safe method for the treatment of EIAA with less trauma and short operation time. It can be used to assess the blood flow and has a good follow-up clinical efficacy.

Source of funding: The study is projected by Sanitation and Health Research Project of Sichuan 
Provincial Health Commission (No: 19PJ215); Scientific research project of Mianyang Municipal Health and Family Planning Commission (No: 201841); Scientific research project of Mianyang Municipal Health Committee (No: 201947).

\section{Conflicts of interest: None}

\section{REFERENCES}

1. Alpagut $\mathrm{U}, \mathrm{Ugurlucan} \mathrm{M}, \mathrm{Kafali} \mathrm{E}$ et al. Aneurysm of the kinked extracranial ICA case report and review of the literature.[J] .Acta Chir. Belg., 2005, 105: 407-9.

2. Nyilas A, Palasthy Z, Mihaly Z, Veres-Lakos E, Szeberin Z. Management of extracranial carotid artery aneurysm. Orv Hetil. 2019;160(21):815-821. doi: 10.1556/650.2019.31390

3. Sharma KJ, Heald C, Simmons JM, Cuff RF. Management of an extracranial internal carotid artery aneurysm secondary to relapsing polychondritis. J Vasc Surg Cases Innov Tech 2020;6(4):576-579. doi: 10.1016/j.jvscit.2020.07.004

4. Sfyroeras GS, Nikolopoulou EA, Moulakakis KG, Lazaris AM, Kakisis JD, Geroulakos G. Extracranial Internal Carotid Artery Aneurysm in a Patient with Marfan Syndrome. Ann Vasc Surg. 2019;57:273.e7-273.e10. doi: 10.1016/j.avsg.2018.09.035

5. Komine H, Teranishi A, Kayahara T, Take Y, Ikegami M, Kikkawa Y, et al. Surgical Management of a Thromobotic Extracranial Carotid Artery Aneurysm: A Case Report. No Shinkei Geka. 2019;47(6):653-658. doi: 10.11477/ mf.1436204000

6. Pourier VEC, van Laarhoven $\mathrm{CJHCM}$, Vergouwen MDI, Rinkel GJE, Borst GJ. Prevalence of extracranial carotid artery aneurysms in patients with an intracranial aneurysm. PLoS One. 2017;12(11): e0187479. doi: 10.1371/ journal.pone.0187479

7. Welleweerd JC, Nelissen BG, Koele D, de Vries JP, Moll FL, Pasterkamp G, et al. Histological analysis of extracranial carotid artery aneurysms. PloS One. 2015;10:e0117915. doi: 10.1371/journal.pone.0117915

8. Welleweerd JC, den Ruijter HM, Nelissen BG, Bots ML, Kappelle LJ, Rinkel GJE, et al. Management of extracranial carotid aneurysm. Eur J Vasc Endovasc Surg. 2015;50:141147. doi: 10.1016 /j.ejvs.2015.05.002

9. Portanova A, Hakakian N, Mikulis DJ, Virmani R, Abdalla WM, Wasserman BA. Intracranial vasa vasorum: insights and implications of imaging. Radiology. 2013;235:667-679. doi: 10.1148/radiol.13112310

10. van 't Hof FN, Ruigrok YM, Lee CH, Ripke S, Anderson $G$, de Andrade $M$, et al. Shared genetic risk factors of intracranial, abdominal and thoracic aneurysms. J Am Heart Assoc. 2016;14;e002603. doi: 10.1161/JAHA.115.002603

11. Donas KP, Schulte S, Pitoulias GA, Siebertz S, Horsch S. Surgical outcome of degenerative versus postreconstructive extracranial carotid artery aneurysms. J Vasc Surg. 2009;49(1):93-98. doi: 10.1016/j.jvs.2008.08.006
12. Jin $\mathrm{C}, \mathrm{Hu} \mathrm{Z}, \mathrm{He} \mathrm{Y}$. A wide-necked extracranial ICA saccular aneurysm with ipsilateral proximal compression. J Clin Ultrasound. 2017;45(2):116-120. doi: 10.1002/jcu.22385

13. Welleweerd JC, Moll FL, de Borst GJ. Technical options for the treatment of extracranial carotid aneurysms. Expert Rev Cardiovasc Ther. 2012;10(7):925-931. doi: 10.1586/ erc.12.61

14. Skora JP, Kurcz J, Korta K, Szyber P, Dorobisz TA, Dorobisz AT. Surgical management of extracranial carotid artery aneurysms. Vasa. 2016;45(3):223-228. doi: 10.1024/03011526/a000528

15. Van Den Berg JC, Engelberger S. Endovascular treatment of extracranial carotid artery aneurysms. J Cardiovasc Surg (Torino). 2015;56(4):547-557.

16. Welleweerd JC, de Borst GJ, de Groot D, van Herwaarden JA, Lo RT, Moll FL. Bare metal stents for treatment of extracranial ICA aneurysms: long-term results. J Endovasc Ther. 2015;22(1):130-134. doi: 10.1177/1526602814566405

17. Daniel K, Tadros RO, Chung C, Patel A, Marin ML, Faries PL. Endovascular Treatment of 2 Synchronous Extracranial Carotid Artery Aneurysms Using StentAssisted Coil Embolization and Double Bare-Metal Stenting. Vasc Endovascular Surg. 2016;50(2):102-106. doi: $10.1177 / 1538574415627869$

18. Haruma J, Hirotsune N, Oka T, Arisawa T. Stent-assisted Coil Embolization to Treat Extracranial Carotid Artery Aneurysm 13 Years after Endarterectomy: A Case Report. NMC Case Rep J. 2019;7(1):23-27. doi: 10.2176/nmccrj. cr.2019-0030

19. Saatci I, Yavuz K, Ozer C, Geyik S, Cekirge HS. Treatment of intracranial aneurysms using the pipeline flow-diverter embolization device: a single-center experience with long-term follow-up results. AJNR Am J Neuroradiol. 2012;33(8):1436-1446. doi:10.3174/ajnr.A3246

20. Robijn SMM, Welleweerd JC, Lo RTH, Moll FL, de Borst GJ. Treatment of an extracranial ICA aneurysm with a flow-diverting stent. J Vasc Surg Cases. 2015;1(2):191-193. doi:10.1016/j.jvsc.2015.04.016

\section{Authors' Contributions:}

JFX and ZBL designed this study and prepared this manuscript, and are responsible and accountable for the accuracy or integrity of the work.

YL collected and analyzed clinical data.

TW significantly revised this manuscript.

JFX and ZBL both considered as first author. 